\title{
Several techniques for the preparation of flour from carcasses of the Pantanal alligator (Caiman crocodilus yacare)
}

\author{
Vitória Regina Takeuchi FERNANDES ${ }^{1}$, Maria Luiza Rodrigues de SOUZA² ${ }^{2 *}$ Eliane GASPARINO², \\ Marcos Eduardo COUTINHO ${ }^{3}$, Jesuí Vergílio VISENTAINER ${ }^{4}$, Elenice Souza dos Reis GOES 5
}

\begin{abstract}
Flour prepared via current assay methodologies from the carcasses of the Pantanal alligator (Caiman crocodilus yacare) was analyzed for its chemical composition, minerals, fatty acids, and sensorial profile. Carcasses of the Pantanal alligator, originating from the Coocrijapan scientific zoo, Cáceres MT Brazil, were utilized. The carcasses were cooked for 60 minutes in a pressure cooker with water containing $2 \%$ salt and $5 \%$ chimichurri. The cooked carcasses were then ground and the mass was used for the manufacture of flour via three techniques: non-smoked, hot-smoked, and liquid-smoked. After each technique, the carcasses were dehydrated at $60^{\circ} \mathrm{C}$ for $3 \mathrm{~h}$ and were ground. Alligator flour was then produced. The moisture of liquid-smoked flour (10.97\%) was higher than that of non-smoked flour (3.78\%) and hot-smoked flour (4.43\%). The flours provided high protein $(57.11 \%-58.27 \%)$ and ash $(23.45-26.42 \%)$ rates, and were predominantly calcium $(6.77 \%-7.69 \%)$, phosphorus (3.67\% - 4.05\%), and iron ( $73.13-273.73 \mathrm{ppm} / 100 \mathrm{mg})$. Smoked-flour had a better acceptance rate by tasters when compared to non-smoked flour. Results show that flours produced from alligator carcasses had high protein, ash, and mineral rates and a reasonable acceptability by most tasters.
\end{abstract}

Keywords: reuse of wastes; hot smoking; liquid smoking; fatty acids; chemical composition.

Practical Application: Flours prepared from the Pantanal alligator may be used to enrich human diets.

\section{Introduction}

Controlled breeding of the Pantanal alligator (Caiman crocodilus yacare) in Brazil has been developed over the last 25 years immediately after the Instituto Brasileiro do Meio Ambiente e Recursos Naturais Renováveis (Ibama), through Decree n. 126 on the $13^{\text {th }}$ of February 1990, authorized the sustainable exploitation of the species.

The breeding of the Pantanal alligator mainly aims to manufacture quality hides that are sold at high prices on the international market (Vieira et al., 2012a). However, the sale of alligator meat is a complementary and profitable activity due to its acceptance in specialized restaurants (Romanelli et al., 2002). Further, alligator meat is very rich in proteins, has low fat rates, and has relatively low cholesterol rates (Vicente et al., 2006; Hoffman \& Cawthorn, 2012).

There is a $65 \%$ alligator carcass yield, comprised of 30 to $40 \%$ meat (Hoffman \& Cawthorn, 2012). Similar to fish meat, the processing of alligator carcasses produces a great amount of residues that are normally directed to animal feed. However, they may also be used in food for human consumption (Stevanato et al., 2007; Franco et al., 2009; Petenuci et al., 2010; Godoy et al., 2013) by including them in several food products. Due to the nutritional quality of the prime matter, the manufacture of flours from the carcasses of the Pantanal alligator may add value to the production chain of the species.

Current assay methodologies were used to analyze the chemical, mineral, fatty acid, and sensorial profile of carcasses from slaughtered Pantanal alligators for the preparation of flours for human diets through different processing techniques.

\section{Materials and methods}

The carcasses of two-year-old Pantanal alligators (Caiman crocodilus yacare), with a mean weight of $3.585 \mathrm{~kg}$, the offspring of wild parents, were used. They were retrieved from the Cooperativa dos Criadores de Jacaré-do-Pantanal (Coocrijapan) at the scientific zoo in Cáceres MT Brazil, through an authorization by Ibama. Carcasses weighing $346 \mathrm{~g}$ were used to manufacture the flours.

Prior to slaughter, the mouths of the alligators were tied and they were fasted for 48 hours. They were kept in tanks and washed in chlorinated water at $0.5 \mathrm{ppm}$ before they were taken to the slaughter room. The alligators were rendered insensible to pain by a shot in the cranial region from an air pistol (Zilka, Gil Equipamentos); they were then de-marrowed, bled, skinned, eviscerated, and the carcasses with meat were washed and cooled between $2-4^{\circ} \mathrm{C}$. After 24 hours, the carcasses were deboned

${ }^{1}$ Programa de Pós-Graduação em Zootecnia, Centro de Ciências Agrárias, Universidade Estadual de Maringá - UEM, Maringá, PR, Brazil

${ }^{2}$ Departamento de Zootecnia, Centro de Ciências Agrárias, Universidade Estadual de Maringá - UEM, Maringá, PR, Brazil

${ }^{3}$ Instituto Brasileiro de Meio Ambiente e dos Recursos Naturais Renováveis, Centro de Conservação e Manejo de Répteis e Anfíbios, Lagoa Santa, MG, Brazil

${ }^{4}$ Departamento de Química, Centro de Ciências Exatas, Universidade Estadual de Maringá - UEM, Maringá, PR, Brazil

${ }^{5}$ Programa de Pós-Graduação em Ciência de Alimentos, Centro de Ciências Agrárias, Universidade Estadual de Maringá - UEM, Maringá, PR, Brazil

*Corresponding author: mlrsouza@uem.br 
and commercial cuts were performed. Bones with meat residues from deboning were identified, wrapped in films, frozen, and stored in a cold room at $-18^{\circ} \mathrm{C}$ until transport.

The carcasses were used to manufacture flours through five replications of three techniques: Treatment $1=$ without smoking; Treatment $2=$ hot smoking; Treatment $3=$ liquid smoking. Carcass lot was the experimental unit (1000 g), and the experimental design was totally randomized.

The carcasses with meat residues were then placed in a pressure cooker with water containing $2 \%$ salt and $0.5 \%$ chimichurri (garlic, onion, parsley, dehydrated sausages, and pepper) and were then cooked for 60 minutes. After cooking, the water was removed and the solid parts (bones, meat, and spices) were ground in an electric meat grinder (Botini B-09, Grupo Botini, São Paulo, Brazil) to obtain a homogeneous mass. The mass for the non-smoked treatment ( $\mathrm{T} 1$ ) was placed in a dehydrator for drying at $60^{\circ} \mathrm{C}$ for three hours.

In the case of hot-smoking (T 2), the cooked and ground carcasses were placed on stainless steel net trays and then in a smoker. A stainless steel artisan smoker was used, and smoke was produced by friction outside the smoking chamber. Smoke was produced by using $8 \mathrm{~cm} \times 8 \mathrm{~cm} \times 80 \mathrm{~cm}$ beams of Eucalyptus globulus. The ground carcasses were smoked for 3 hours at $60^{\circ} \mathrm{C}$, whilst cooking gas was employed for the maintenance of the temperature.

The liquid-smoking technique (T 3) entailed spraying the mass with a solution of water containing liquid Krakismoke FI 9027 Plus $^{\circ}$ (6:1), which was then placed in a dehydrator at $60^{\circ} \mathrm{C}$ for 3 hours.

After the three types of dehydration, they were individually placed in a cutter and ground in a Willey grinder (TE-650, Willey). The samples were vacuum-wrapped for later analyses.

\subsection{Chemical composition and calorie, calcium, iron, and phosphorus rates}

The chemical composition of the in natura carcasses and the several types of flour were determined. Moisture and ash rates were analyzed following Associations of Official Analytical Chemists (2005). Crude protein rates were determined by the semi-micro Kjeldahl method described by Silva \& Queiroz (2002), while total lipids were calculated according to the technique by Bligh \& Dyer (1959). All processes were performed in triplicate. Rates of carbohydrates were calculated by determining the difference of the other components (Brasil, 2003) and total calorie rate was obtained by adding the product of the mean rates of protein, lipids, and carbohydrates, respectively multiplied by 4,9 , and 4 , (Souci et al., 2000).

For the analysis of calcium and iron of the manufactured flour, the sample's digestion was undertaken in an acid medium and determined by flame atomic absorption spectrometry (FAAS), per Zhou et al. (1998). Total phosphorus was determined by using ammonium phosphomolybdate and by UV-VIS spectrophotometry, per Eijsink et al. (1997).

\subsection{Fatty acids}

Fatty acids rates were determined by trans-esterifying total lipids following the ISO methodology. The methyl esters of fatty acids were separated in a gas chromatograph Varian 3380, equipped with a flame deionization detector and cast silica capillary column Select FAME CP-7420 (100 m long; $0.25 \mathrm{~mm}$ internal diameter; $0.25 \mu \mathrm{m}$ cyanopropyl). $\mathrm{H}_{2}$ flow was $1.0 \mathrm{~mL} / \mathrm{min}$, with $30 \mathrm{~mL} / \mathrm{min}$ of $\mathrm{N}_{2}$ (makeup), 30 and $300 \mathrm{~mL} / \mathrm{min}$ for $\mathrm{H}_{2}$ and synthetic air for the detector flame. The injected volume was $0.2 \mu \mathrm{L}$, with a split ratio of 1:80; injector and detector temperatures were respectively 220 and $240^{\circ} \mathrm{C}$, whereas column temperature reached $165^{\circ} \mathrm{C}$ for $18 \mathrm{~min}$ and reached $235^{\circ} \mathrm{C}$ at a rate of $4^{\circ} \mathrm{C} / \mathrm{min}$ over $24.5 \mathrm{~min}$.

Fatty acids were identified through the following analyses: comparison of retention times of Sigma (USA) standard methyl esters with samples, and comparison of Equivalent Chain Length (ECL) of sample methyl esters with rates from Visentainer (2003) and Stránsky et al. (1997).

\subsection{Sensorial profile}

Sensorial analysis was undertaken with 50 non-trained tasters. The project was authorized by the Ethics Committee in Research with Humans of the Universidade Estadual de Maringá, Maringá PR Brazil, by Resolution n. 196/96 and approval n. 149/2010.

Flours from the three treatments were supplied to tasters in disposable cups that were identified by three randomized numbers, along with a glass of water. Color, aroma, taste, texture, salt rate, physical aspect, and overall acceptance were evaluated by a nine-point hedonic scale, ranging between 'I like it very much' (=9) and 'I dislike it very much' (=1) (Dutcosky, 2007). The Expression 1 was used to evaluate the products' Acceptability Index (AI):

$$
A I \%=\frac{A}{B} \times 100
$$

where $\mathrm{A}=$ mean score for the product; $\mathrm{B}=$ maximum score of scale.

A 5-point hedonic scale was employed to evaluate purchase intention, with score $5=$ 'I will surely buy it' and score $1=$ 'I will surely not buy it', using procedures described by Meilgaard et al. (1991) and Damásio \& Silva (1996).

\subsection{Statistical analyses}

Results of the chemical composition analyses were submitted to analysis of variance and means compared by Tukey's test at 5\% with Statistical Analysis System (SAS, SAS Inst. Inc. Cary NC USA). The description analysis of flours was used for minerals and fatty acids.

PROC GENMOD of SAS was employed for the statistical sensorial analyses with inverse gamma distribution's probability density function.

\section{Results and discussion}

Significant differences $(\mathrm{P}<0.05)$ were reported for the three techniques in flour fabricated from the Pantanal alligator carcasses with regard to chemical composition and variables that were analyzed (moisture, crude protein, lipids, and ashes) (Table 1). 
Table 1. Chemical composition and caloric rate of carcasses and flours manufactured from the carcasses of juvenile Pantanal alligators (Caiman crocodilus yacare).

\begin{tabular}{|c|c|c|c|c|c|}
\hline \multirow{2}{*}{ Nutrients (\%) } & \multirow{2}{*}{$\begin{array}{l}\text { Carcasses } \\
\text { in natura }\end{array}$} & \multicolumn{3}{|c|}{ Flours } & \multirow{2}{*}{$\mathrm{P}$ rate } \\
\hline & & Without smoking & Hot smoking & Liquid smoking & \\
\hline Moisture & $71.28 \pm 0.82$ & $3.78 \pm 0.35 \mathrm{~b}$ & $4.43 \pm 1.5 \mathrm{~b}$ & $10.97 \pm 1.77 \mathrm{a}$ & $<0.0001$ \\
\hline Crude protein & $23.52 \pm 0.39$ & $58.27 \pm 1.07 \mathrm{a}$ & $57.92 \pm 0.99 \mathrm{ab}$ & $57.11 \pm 0.69 \mathrm{~b}$ & 0.0426 \\
\hline Lipids & $3.94 \pm 1.05$ & $12.11 \pm 0.69 \mathrm{a}$ & $10.06 \pm 0.50 \mathrm{~b}$ & $10.06 \pm 0.65 b$ & $<0.0001$ \\
\hline Ashes & $1.19 \pm 0.17$ & $26.42 \pm 0.90 \mathrm{a}$ & $25.45 \pm 0.40 \mathrm{a}$ & $23.45 \pm 1.24 \mathrm{~b}$ & $<0.0001$ \\
\hline Carbohydrates & $0.07 \pm 2.62$ & - & 2.14 & - & - \\
\hline Caloric rate $(\mathrm{Kcal} / 100 \mathrm{~g})$ & $103.66 \pm 8.74$ & $339.75 \pm 4.82 \mathrm{a}$ & $330.75 \pm 5.91 \mathrm{~b}$ & $312.59 \pm 5.46 \mathrm{c}$ & $<0.0001$ \\
\hline
\end{tabular}

Data given in means \pm standard deviation. Means on the same line followed by different letters differ by Tukey's test $(\mathrm{P}<0.05)$.

There were $67.5 \%, 66.85 \%$, and $60.31 \%$ decreases in moisture rates respectively for non-smoking, hot-smoking, and liquid-smoking techniques with regard to in natura carcasses following the dehydration process. A decrease in moisture caused an increased concentration of the other nutrients (crude protein, lipids, and ashes), which improved the flours' nutritional quality.

Non-smoked flour had a higher concentration of crude protein and lipids (58.27 and $12.11 \%$ respectively) when compared to the other flours, thereby causing a higher caloric rate $(339.75 \mathrm{kcal} / 100 \mathrm{~g})$. There was no significant difference $(\mathrm{P}>0.05)$ for moisture and ash rates among the non-smoked and hot-smoked treatments, even though in the same parameters, they differed significantly from liquid smoked flour. Non-smoked flour had a higher lipid rate than the smoked ones. The smoking process leads to fat loss via the leaching process due to heating (Sigurgisladottir et al., 2000), which probably caused the smoked flours to have a smaller lipid content in relation to non-smoked flour.

Liquid-smoked flour had a higher moisture rate (10.97\%), perhaps due to the incorporation of liquid smoke to the carcasses. Since a higher moisture rate in the flour affects shelf life, smoking for a longer period of time is recommended in liquid-smoking. In fact, the moisture rate for animal products is $12 \%$ according to the Rules for Industrial and Sanitary Inspection for Animal-Originating Products (RIISPOA) (Brasil, 1997) and thus, registered rates are satisfactory.

Crude protein rates for flours are compatible with those reported for flours made from the viscera of the Pantanal alligator, namely, 53.90\% (Romanelli \& Schmidt, 2003). Furthermore, viscera flour provided values of 3.06\% moisture, $33.77 \%$ lipids, and $8.17 \%$ ashes (Romanelli \& Schmidt, 2003), which were different from rates in the current analysis, especially because of the different prime matters that were employed in the two assays (carcass and viscera).

The hot- and liquid-smoked processes decreased lipid rates of the smoked flours $(10.06 \%)$ when compared to those from the non-smoked process $(12.11 \%)$. The finding was registered by Vieira et al. (2012b) when they compared different techniques in the preparation of flour from tilapia carcasses (cooked and smoked carcasses). In fact, in the case of moisture, crude protein, ashes, and lipids, the authors reported respective values of $2.71 \%$, $50.04 \%, 38.03 \%$, and $6.93 \%$ for cooked carcasses and $4.05 \%$, $49.65 \%, 39.45 \%$, and $5.45 \%$ for cooked and smoked carcasses.
High ash rates for the different flours are due to the bones in the carcasses that were used as prime matter. It should be underscored that non-smoked flour and hot-smoked flour had statistically equal ash rates, or rather, 26.42 and $25.45 \%$, respectively. These rates are higher than that of liquid-smoked flour $(23.45 \%)$ which may be due to the incorporation of the liquid-smoking, thereby causing a higher moisture rate in the final product and consequently, lower ash, protein, and lipid rates.

Tilapia fishbone flour registered values of $14.2 \%$ moisture, $40.8 \%$ crude protein, $25.3 \%$ total lipids, and $18.3 \%$ fixed mineral residues (Petenuci et al., 2010). According to Franco et al. (2013), flour from tilapia carcasses provided $2.5 \%$ moisture, $45.32 \%$ crude protein, $6.93 \%$ ether extract, and $38.03 \%$ ashes. Differences may be related to methodologies employed for the preparation of the flour, which may have affected the levels of chemical composition.

The flour's high rates of mineral matter are congruent to calcium, phosphorus, and iron concentrations (Table 2), where average rates of calcium varied between $6.77 \%$ and $7.69 \%$, phosphorus between $3.67 \%$ and $4.05 \%$, and iron between $73.13 \mathrm{ppm} / 100 \mathrm{mg}$ and $273.73 \mathrm{ppm} / 100 \mathrm{mg}$ for the different treatments.

The three techniques for the preparation of flour from the Pantanal alligator carcass revealed similar average rates for calcium and phosphorus. Iron in the hot-smoked flour produced a higher average $(273.73 \mathrm{mg} / \mathrm{kg})$, followed by non-smoked flour $(106.43 \mathrm{mg} / \mathrm{kg})$ and liquid-smoked flour $(73.13 \mathrm{mg} / \mathrm{kg})$. The lower iron content in this flour is probably due to the lower content of ash in liquid-smoked flour (Table 1). Aromatized flour from tilapia carcasses prepared by Godoy et al. (2013) provided $1.78 \%$ calcium, $5.47 \%$ phosphorus, and $2.36 \mathrm{mg} / 100 \mathrm{~g}$ iron. In the current analysis, flour is richer in calcium and iron than in tilapia's, mainly due to the prime matter that is involved. Although they are different species, all the thick bones of the alligator's carcass are taken into consideration, whereas the thin spine bone and ribs of the tilapia are involved.

Table 3 provides a list of the fatty acids that were identified in the different flours. Oleic (18:1n-9), palmitic (16:0), and stearic (18:0) were predominant in the current analysis, with average rates of $36.81 \%, 22.16 \%$, and $18.69 \%$ respectively for non-smoked flour; $39.86 \%, 24.47 \%$, and $19.98 \%$ for hot-smoked flour; and $39.80 \%, 23.67 \%$, and $19.93 \%$ for liquid-smoked flour. 
Animal (meat, milk, and derived products) and vegetal (coconut and cocoa) fats are sources of saturated fatty acids (Martin et al., 2006). Of the diet's fatty acids, palmitic fat is the most abundant and raises the plasmatic concentration of cholesterol (Lottenberg, 2009). Palmitic fatty acid was also high in the current analysis and may be found among the three major fatty acids.

Vicente et al. (2007) reported that the predominant fatty acids in the Pantanal alligator were oleic, palmitic, and linoleic

Table 2. Mean rates of minerals in the flour prepared from the carcass of the Pantanal alligator (Caiman crocodilus yacare).

\begin{tabular}{cccc}
\hline Flour & Calcium (\%) & Phosphorus (\%) & Iron $(\mathrm{mg} / \mathrm{kg})$ \\
\hline Non-smoked & 7.65 & 4.05 & 106.43 \\
Hot-smoked & 7.69 & 4.03 & 273.73 \\
Liquid-smoked & 6.77 & 3.67 & 73.13 \\
\hline
\end{tabular}

Table 3. Profile of fatty acids (\%) in the flours prepared from carcasses of juvenile Pantanal alligator (Caiman crocodilus yacare).

\begin{tabular}{cccc}
\hline \multirow{2}{*}{ Fatty acids } & \multicolumn{3}{c}{ Flours } \\
\cline { 2 - 4 } & Non-smoked & Hot-smoked & Liquid-smoked \\
\hline $14: 0$ & 1.75 & 2.11 & 1.99 \\
$16: 0$ & 22.16 & 24.47 & 23.67 \\
$18: 0$ & 18.69 & 19.98 & 19.93 \\
$18: 1 \mathrm{n}-9$ & 36.81 & 39.86 & 39.80 \\
$18: 1 \mathrm{n}-7$ & 3.90 & 2.00 & 2.18 \\
$18: 2 \mathrm{n}-6$ & 5.90 & 5.97 & 6.33 \\
$20: 5 \mathrm{n}-3$ & 2.96 & 3.06 & 3.60 \\
$22: 6 \mathrm{n}-3$ & 7.84 & 2.55 & 2.80 \\
$\Sigma$ AGS & 42.60 & 46.56 & 45.29 \\
$\Sigma$ AGMI & 40.72 & 41.86 & 41.98 \\
¿AGPI & 16.69 & 11.58 & 12.73 \\
AGPI/AGS & 0.39 & 0.25 & 0.28 \\
n-3 & 10.79 & 5.60 & 6.40 \\
n-6 & 5.90 & 5.97 & 6.33 \\
n6/n3 & 0.54 & 1.06 & 0.98 \\
\hline
\end{tabular}

$\Sigma$ AGS=Sum of saturated fatty acids; $\Sigma$ AGMI=Sum of monounsaturated fatty acids; $\Sigma$ AGPI=Sum of polyunsaturated fatty acids; AGPI/AGS=Ratio between polyunsaturated and saturated fatty acids; $n-3=$ sum of fatty acids of the series n-3;n-6=sum of fatty acids of the series $n-6$. acids and totaled $64.80 \%$. The different types of flours in the current study provided two fatty acids that were recognized by Vicente et al. (2007), although the percentage for the three fatty acids was lower than that mentioned by the authors. Furthermore, Petenuci et al. (2010) evaluated tilapia fishbone flour, and Souza et al. (2008) and Stevanato et al. (2007) evaluated tilapia head flour and reported a predominance of palmitic (16:0), oleic (18:1n-9), and linoleic (18:2n-6) oils.

Rates of saturated fatty acids varied between $42.60 \%$ and $46.56 \%$, rates of monounsaturated fatty acids varied between $40.72 \%$ and $41.98 \%$, and rates of polyunsaturated fatty acids varied between $11.58 \%$ and $16.69 \%$. Vicente et al. (2007) reported that the meat of wild animals have $36.49 \%$ saturated fatty acids, $41.71 \%$ monounsaturated fatty acids, and $22.07 \%$ polyunsaturated fatty acids. According to these authors, polyunsaturated fatty acids are high and decrease serum cholesterol levels. Rates in the current analysis of polyunsaturated fatty acids were lower than those in wild animals, whereas saturated fatty acids were higher, and monounsaturated were equal.

The $\mathrm{n} 6 / \mathrm{n} 3$ relationship that is recommended for human diets by the WHO and FAO lies between 5:1 and 10:1 (Elvevoll \& James, 2000). Higher ratios decrease the production of eicosapentaenoic acid, which contributes towards the development of allergies, inflammation, and cardiovascular diseases (Martin et al., 2006). Rates in the current analysis $(0.54-1.06)$ were lower than those recommended, even though this fact was expected since meat in general has a lower rate of polyunsaturated fatty acids.

There were significant differences with regards to the sensorial profile involving color, aroma, taste, general aspect, acceptance index, and purchase intention $(\mathrm{P}<0.05)$ (Table 4$)$. There was no difference $(\mathrm{P}>0.05)$ only with regards to texture and salt rates among the different types of flour. The two smoked flours had a better acceptance with regard to color, aroma, taste, and general acceptance than non-smoked flour.

The highest scores for smoked flour provided a better acceptance index, or rather, between 74.05 and $71.24 \%$ for hot-smoked flour and liquid-smoked flours, respectively. Rates were higher than the index in non-smoked flour (61.86\%).

Table 4. Sensorial attributes, acceptance index, and purchase intention of different flours prepared from juvenile Pantanal alligators (Caiman crocodilus yacare).

\begin{tabular}{ccccc}
\hline \multirow{2}{*}{ Attributes } & \multicolumn{3}{c}{ Flours } & \multirow{2}{*}{ P rate } \\
\cline { 2 - 4 } & Non-smoked & Hot-smoked & Liquid-smoked & 0.0319 \\
Color $^{1}$ & $6.45 \pm 1.53 \mathrm{~b}$ & $7.25 \pm 1.54 \mathrm{a}$ & $6.87 \pm 1.45 \mathrm{ab}$ & $0.20 \pm 2.26 \mathrm{a}$ \\
Aroma $^{1}$ & $4.77 \pm 2.04 \mathrm{~b}$ & $6.12 \pm 1.94 \mathrm{a}$ & $5.91 \pm 2.04 \mathrm{a}$ & 0.0009 \\
Taste $^{1}$ & $4.37 \pm 2.03 \mathrm{~b}$ & $6.12 \pm 2.20 \mathrm{a}$ & $6.34 \pm 1.81$ & 0.0001 \\
Texture $^{1}$ & $5.92 \pm 1.91$ & $6.58 \pm 1.79$ & $6.46 \pm 1.79$ & 0.1955 \\
Salt rate $^{1}$ & $5.74 \pm 2.17$ & $6.66 \pm 1.75$ & $7.20 \pm 1.46 \mathrm{ab}$ & 0.00534 \\
Aspect $^{1}$ & $6.54 \pm 1.81 \mathrm{~b}$ & $7.56 \pm 1.26 \mathrm{a}$ & $6.02 \pm 1.93 \mathrm{a}$ & 0.0009 \\
General,acceptance $^{1}$ & $5.04 \pm 1.80 \mathrm{~b}$ & $6.45 \pm 1.83 \mathrm{a}$ & $71.24 \pm 14.69 \mathrm{a}$ & 0.0001 \\
Acceptance Index $(\%)^{\text {Purchase intention }}{ }^{2}$ & $61.86 \pm 14.46 \mathrm{~b}$ & $74.05 \pm 14.54 \mathrm{a}$ & $3.24 \pm 1.22 \mathrm{a}$ & 0.0005 \\
\hline
\end{tabular}

${ }^{1}$ Hedonic scale between 1 (I didn't like it very much) and 9 (I liked it very much). ${ }^{2}$ Hedonic scale between 1 (I will surely not buy it) and 5 (I will surely buy it). Data given in mean \pm standard deviation. Means on the same line followed by different letters differ by Tukey's test $(\mathrm{P}<0.05)$. 
Based on the minimum index (70\%) for the product to be well accepted on the market (Dutcosky, 2007), it may be surmised that smoked flours would be well accepted if available on the market or if they are inserted in other food products. The above observations may be supported by the purchase intention, which was higher $(\mathrm{P}<0.05)$ for smoked flour when compared to that for non-smoked ones. Similar results to the current analysis were reported by Vieira et al. (2012b), who studied tilapia carcass flour obtained from cooked carcasses and from cooked and smoked carcasses, and reported that smoked flour had a better acceptance.

Further studies on the types of flour prepared from juvenile Pantanal alligator carcasses should evaluate shelf life and inclusion in different products for human diets such as meat products, extruded snacks, biscuits, soups, broths, and others.

\section{Conclusions}

Types of flour prepared from the carcasses of the Pantanal alligator (Caiman yacare) revealed high protein, ashes, and mineral rates. Non-smoked and hot-smoked flours had lower moisture rates. Major fatty acids were comprised of oleic (18:1n-9), palmitic (16:0), and stearic (18:0) acids, although rates were lower for non-smoked flour.

Hot-smoked and liquid-smoked flours were better accepted when compared to non-smoked flour.

The different types of flour may be included in several products for humans when the nutritional quality of the flours is taken into account. In fact, the diets are nutritionally enriched.

\section{References}

Associations of Official Analytical Chemists - AOAC. (2005). Official Methods of Analyses of the Association of Analytical Chemists (18th ed.). Washington, DC: AOAC.

Bligh, E. G., \& Dyer, W. J. (1959). A rapid method of total lipid extraction and purification. Canadian Journal of Biochemistry and Physiology, 37(8), 911-917. http://dx.doi.org/10.1139/o59-099. PMid:13671378.

Brasil, Ministério da Agricultura, Pecuária e Abastecimento. (1997). Regulamento da Inspeção Industrial e Sanitária de Produtos de Origem animal (RIISPOA). Brasília: Ministério da Agricultura. Seção II Derivado do Pescado, Artigo 466.

Brasil, Ministério da Saúde. (2003, December 23). Resolução RDC n ${ }^{\circ}$ 360 , de 23 de dezembro de 2003. Aprova o regulamento técnico sobre rotulagem nutricional de alimentos embalados. Diário Oficial [da] República Federativa do Brasil.

Damásio, M. H., \& Silva, M. A. A. P. (1996). Curso de treinamento em análise sensorial: apostila. Campinas: Fundação Tropical de Tecnologia "André Tosello".

Dutcosky, S. D. (2007). Análise sensorial de alimentos. Curitiba: Champagnat.

Eijsink, L. M., Krom, M. D., \& Lange, G. J. (1997). The use of sequential extraction techniques for sedimentary phosphorus in eastern Mediterranean sediments. Marine Geology, 139(1-4), 147-155. http://dx.doi.org/10.1016/S0025-3227(96)00108-9.

Elvevoll, E. O., \& James, D. G. (2000). Potential benefits of fish for maternal, foetal and neonatal nutrition: a review of the literature. Food, Nutrition and Agriculture, 27, 28-39.
Franco, M. L. R. S., Abreu, B. B., Saccomani, A. P. O., Vesco, A. P. D., Vieira, V. I., Mikcha, J. M. G., Gasparino, E., \& Delbem, A. C. B. (2013). Elaboración de cookies y galletas com inclusión de harina de pescado. Infopesca Internacional, 53, 30-33.

Franco, M. L. R. S., Godoy, L. C., Souza, N. E., Stevanato, F. B., Franco, N. P., \& Visentainer, J. V. (2009). Aproveitamento de carcaças de pacu (Piaractus mesopotamicus). Revista Aqüicultura \& Pesca, 39, 52-58.

Godoy, L. C., Franco, M. L. R. S., Souza, N. E., Stevanato, F. B., \& Visentainer, J. V. (2013). Development, preservation, and chemical and fatty acid profiles of Nile tilapia carcass flour for human feeding. Journal of Food Processing and Preservation, 37(2), 93-99. http:// dx.doi.org/10.1111/j.1745-4549.2011.00624.x.

Hoffman, L. C., \& Cawthorn, D. M. (2012). What is the role and contribution of meat from wildlife in providing high quality protein for consumption. Animal frontiers, 2(4), 40-53. http://dx.doi. org/10.2527/af.2012-0061.

Lottenberg, A. M. P. (2009). Importância da gordura alimentar na prevenção e no controle de distúrbios metabólicos e da doença cardiovascular. Arquivos Brasileiros de Endocrinologia e Metabologia, 53(5), 595-607. http://dx.doi.org/10.1590/S0004-27302009000500012. PMid:19768250.

Martin, C. A., Almeida, V. V. D., Ruiz, M. R., Visentainer, J. E. L., Matshushita, M., Souza, N. E. D., \& Visentainer, J. V. (2006). Ácidos graxos poliinsaturados ômega-3 e ômega-6: importância e ocorrência em alimentos. Revista de Nutrição, 19(6), 761-770.

Meilgaard, M., Civile, G. V., \& Carr, B. T. (1991) Sensory evaluation techniques (2nd ed.). Boca Raton: CRC Press.

Petenuci, M. E., Stevanato, F. B., Morais, D. R., Santos, L. P., Souza, N. E., \& Visentainer, J. V. (2010). Composição e estabilidade lipídica da farinha de espinhaço de tilapia. Ciência e Agrotecnologia, 34(5), 1279-1284. http://dx.doi.org/10.1590/S1413-70542010000500028.

Romanelli, P. F., \& Schmidt, J. (2003). Estudo do aproveitamento das vísceras do jacaré do pantanal (Caiman crocodilus yacare) em farinha de carne. Ciência e Tecnologia de Alimentos, 23, 12-24. http://dx.doi. org/10.1590/S0101-20612003000400025.

Romanelli, P. F., Caseri, R., \& Lopes, J. F., Fo (2002). Processamento da carne do Jacaré do Pantanal (Caiman crocodilus yacare). Ciência e Tecnologia de Alimentos, 22(1), 70-75. http://dx.doi.org/10.1590/ S0101-20612002000100013.

Sigurgisladottir, S., Sigurdardottir, M. S., Torrissen, O., Vallet, J. C., \& Hafsteinsson, H. (2000). Effects of different salting and smoking processes on the microstructure, the texture and yield of Atlantic salmon (Salmo salar) fillets. Food Research International, 33(10), 847-855. http://dx.doi.org/10.1016/S0963-9969(00)00104-6.

Silva, D. J., \& Queiroz, A. C. (2002). Análises de alimentos (métodos químicos e biológicos) (3rd ed.). Viçosa: Editora UFV.

Souci, S. W., Fachman, H., \& Kraut, E. (2000). Foods Composition and Nutrition Tables(6th ed.). Stuttgart: Medpharm Scientific Publishers.

Souza, N. E., Stevanato, F. B., Garcia, E. E., Visentainer, J. E., Zara, R. F., \& Visentainer, J. V. (2008). Supplemental dietary flaxseed oil affects both neutral and phospholipid fatty acids in cultured tilapia. European Journal of Lipid Science and Technology, 110(8), 707-713. http://dx.doi.org/10.1002/ejlt.200700245.

Stevanato, F. B., Petenucci, M. E., Matsushita, M., Mesomo, M. C., Souza, N. E., Visentainer, J. E. L., Almeida, V., \& Visentainer, J. V. (2007). Avaliação química e sensorial da farinha de resíduo de tilápias na forma de sopa. Ciência e Tecnologia de Alimentos, 27(3), 567-571. http://dx.doi.org/10.1590/S0101-20612007000300022.

Stránsky, K., Jursík, T., \& Vitek, A. (1997). Standard equivalent chain length values of monoenic and polyenic (methylene interrupted) 
fatty acids. Journal of High Resolution Chromatography, 20(3), 143158. http://dx.doi.org/10.1002/jhrc.1240200305.

Vicente, J., No, Bressan, M. C., Faria, P. B., Oliveira, J., Vieira, M. T. A. S., \& Kloster, M. (2006). Composição centesimal e colesterol da carne de jacaré-do pantanal (Caiman yacare Daudin 1802) oriundo de zoocriadouro e habitat natural. Ciência e Agrotecnologia, 30(4), 701-706. http://dx.doi.org/10.1590/S1413-70542006000400016.

Vicente, J., No, Bressan, M. C., Rodrigues, E. C., Kloster, M. A., Santana, M. T. A. (2007). Avaliação físico química da carne de jacaré-dopantanal (Caiman yacare Daudin 1802) de idades diferentes. Ciência e Agrotecnologia, 31(5),1430-1434.

Vieira, J. P., Silva, T. J. P., Freitas, M. Q., Fontenelle, G., Lindote, H. C. F., \& Freitas, M. A. M. (2012a). Caracterização do processo de rigor mortis do músculo Ilio-ischiocaudalis de jacaré-do-pantanal
(Caiman crocodilus yacare) e maciez da carne. Ciência Rural, 42(3), 567-572. http://dx.doi.org/10.1590/S0103-84782012000300029.

Vieira, V. I., Souza, M. L. R., Mikcha, J. M. G., \& Bielaswki, K. (2012b) Alternativas tecnológicas para o aproveitamento das carcaças de tilápia na elaboração de farinha para consumo humano. In III Simpósio de Gestão do Agronegócio e III Mostra de Trabalhos Científicos, Maringá, Paraná, Brasil.

Visentainer, J. V. (2003). Composição de ácidos graxos e quantificação dos ácidos LNA, EPA e DHA no tecido muscular de tilápias (Oreochromis niloticus), submetidas a diferentes tratamentos com óleo de linhaça (Doctoral thesis). Universidade Estadual de Campinas, Campinas.

Zhou, H. Y., Cheung, R. Y. H., Chan, K. M., \& Wong, M. H. (1998). Metal concentrations in sediments and tilapia collected from inland waters of Hong Kong. Water Research, 32(11), 3331-3340. http:// dx.doi.org/10.1016/S0043-1354(98)00115-8. 